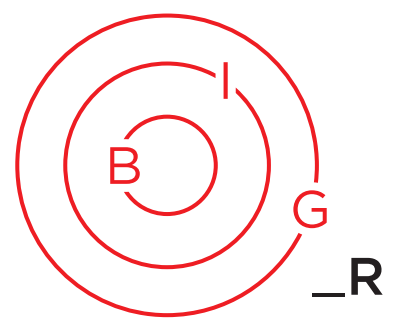

ESSAY

SPECIAL ISSUE

\title{
Indian Borders in the Era of COVID-19
}

\author{
Sanjiv Krishan Sood i \\ Dhananjay Tripathi ii
}

After the outbreak of COVID-19, India closed its international borders and at the domestic level restricted intra-state movements. This paper underlines the impacts on Indian border security, management, trade, and life in the borderlands. The paper also discusses how new internal borders were erected during the nationwide lockdown.

\section{Borders Before COVID-19: An overview}

India has about 14,945 kilometres of land borders with its seven neighbours, namely Pakistan, Afghanistan, China, Nepal, Bhutan, Bangladesh and Myanmar. The 106-kilometre-long border with Afghanistan is along what is called Pakistan Occupied Kashmir (POK). India's borders also include the Line of Control (LoC) in Kashmir and also, recently much in the news, the disputed Line of Actual Control (LAC) with China. Besides the land borders, India also has 7693 kilometres of coastline. The borders with Pakistan and Bangladesh are guarded by the Border Security

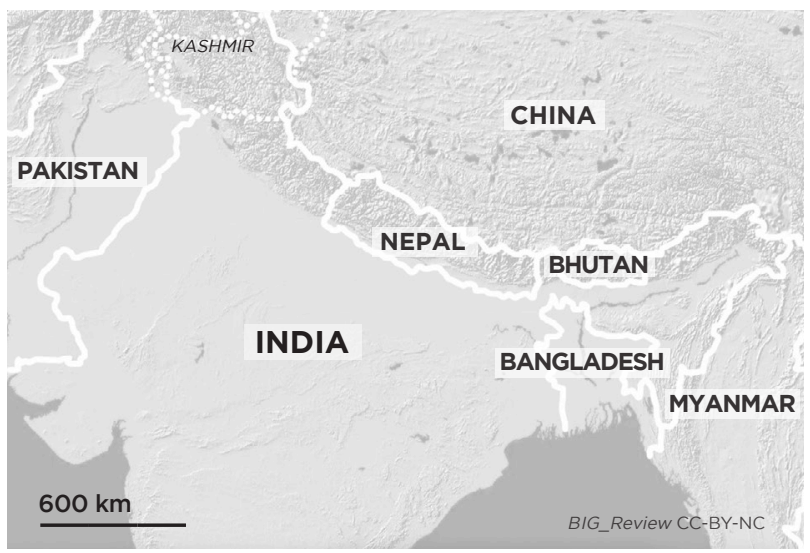

Force (BSF). The Borders with Nepal and Bhutan are protected by the Shashatra Seema Bal (SSB) (Armed Border Force).

In contrast, the border with China, including the LAC, are guarded by Indo-Tibetan Border Police (ITBP) along with the Indian army. Similarly, the LoC in Kashmir is guarded by the army with some units of BSF placed under its Operational Command. The COVID-19 pandemic has put extra pressure on border troops who even otherwise are under a lot of strain due to the manpower-intensive border guarding practices prevalent along Indian borders.

Most of the borders in South Asia were drawn by the British for their political, economic and security considerations (Tripathi and Chaturvedi 2019). These borders ignored socio-cultural realities of South Asia. Even after the departure of the British, independent states (viz. India, Pakistan, Bangladesh, Myanmar) inherited these lines and made little effort to alter them (Tripathi 2015). Borders of India with Pakistan and Bangladesh are highly securitised with a border fence constructed by India to prevent criminals, smugglers, and illegal immigrants crossing over to India. Both these borders have the dubious distinction of being

i Sanjiv Krishan Sood, former Additional Director, Border Security Force, India. Email: sks_2@rediffmail.com

ii Dhananjay Tripathi, PhD, Senior Assistant Professor, Department of International Relations, South Asian University, New Delhi, India. Email: dhananjay@sau.ac.in 
amongst the five most dangerous borders of the world (NewsORB360 2020). However, the India-Nepal and India-Bhutan borders are open borders as a result of treaties between India and Nepal and between India and Bhutan. Articles 6 and 7 of the India-Nepal Treaty of Peace and Friendship (1950) grants the nationals of one country the same privileges in territories of another on a reciprocal basis. This includes freedom to move from one state to the other without any requirement of a passport or visa. Similar provisions are included in the Treaty of Friendship signed between India and Bhutan (1949).

Thus, India has open borders as well as securitised borders and different security agencies for border management. As one of the most affected nations by COVID-19, several changes in border management are inevitable. The remainder of this essay analyses some of the necessary and expected alterations in border management that we may witness in future.

\section{Post-COVID-19 and India's International Borders}

India is one of the worst-hit countries from the novel coronavirus pandemic, just behind the US in terms of total number of cases (the US has the highest number of positive cases in the world). At present India has 7,120,538 confirmed cases and lost 109,150 citizens due to the pandemic (World Health Organization 2020). The first case in India was reported on 3 January 2020, and in March, the cases started rising dramatically. The government of India locked down the country on 25 March. The lockdown continued till 31 May. Thereafter, the government started the unlocking process; still, this long and sudden lockdown adversely impacted the Indian economy. Several related issues require attention. This paper focuses on the impact of COVID-19 on Indian borders.

\section{Aviation industry and airports:}

As one of the leading economies of the world, India is well connected internationally through air and freight transportation. In 2019, the Indian aviation industry registered impressive growth with the number of international passengers increasing by 6.9 percent over 2018 (Chandra 2019). The initial spread of the coronavirus pandemic in India came from international air travellers before necessary protocols could be put in place. International travel was suspended on 22 March, 2020. It remains suspended to date except for select flights returning stranded Indian nationals from other countries or sending back foreign nationals to their respective countries. Resultantly, international careers are facing the burden of having to maintain idle assets without any revenue generation. The necessity of imposing protocols to prevent the spread of the virus has also resulted in increased cost of operation of the airports and the border personnel viz. customs and immigration officials. The extra time required for clearance for each passenger also disrupted schedules. The pandemic imposed additional costs on international travel as more facilities had to be created at the airports.

\section{Border trade and movement of people:}

As indicated above, India shares land borders with almost all the countries of South Asia. The IndiaPakistan and India-Bangladesh borders being heavily securitised, border crossing is possible only through authorised crossing points. These points, called Land Custom Stations (LCSs) and International Check Posts (ICPs), were closed for international traffic during the lockdown. These are now being progressively opened and a certain amount of trade and transit is allowed. Closure of the border crossing points along the IndiaBangladesh border created difficulties for Nepal and Bhutan (both being landlocked) as the transit trade through these was heavily affected.

The India-Nepal and India-Bhutan borders were open borders. Crossings could take place anywhere along the border. Borderlanders in these communities routinely crossed the borders for work. According to the estimation of Radhika Halder, 279,000 Nepali migrant labourers worked in India, and also Indian labourers worked in Nepal. The pandemic has caused significant disruption of movement through authorised crossing points. Many of these labourers were stuck and wanted to move back to their respective countries (Halder 2020). Guarding every inch of these open and heavily populated borders is difficult. Nearly 1,500 stranded workers, therefore, resorted to adopting challenging routes to cross (ANI 2020). There were "photos and videos of Nepali nationals swimming across Mahakali river to get home which had gone viral on social media" (Bhattarai 2020). Several Nepali migrant workers unwillingly stayed at Uttarakhand, an Indian state that shares borders with Nepal. Unlike the India-Nepal border, there was not much distress at the India-Bhutan border. This is because not many migrant workers from India go to Bhutan. Those who were stranded in Bhutan were brought back after some time.

The primary cause of disruption at these two borders was the lack of preparedness to deal with the pandemic. There were very few quarantine facilities near these borders and also no specific relief camps. There is no indication when the movement of people will normalise near the India-Nepal and India-Bhutan borders. The closures have adversely affected the income of migrant labourers on both sides and also the movements of merchandise trucks. Things may return to relative normal at the India-Bhutan border soon, but the recent tension along the India-Nepal border may add to the problem and delay normalcy. It is difficult to 
predict at this juncture how things will evolve along the India-Nepal border. It appears that security has been tightened in the form of enhanced surveillance and more extensive deployment of troops on the pretext of COVID-19.

\section{Border security and management:}

As in other spheres, the coronavirus pandemic has adversely impacted the border guarding and management operations. The manpower-intensive border guarding practices prevalent on the borders of India make the border guards vulnerable to infection. The internal data of BSF reveals that at the start of the last week of July 2020, BSF had a total of 2889 COVID-19positive cases, i.e. about 1.15 percent of the total force of about 250,000, compared to about 0.089 percent of the entire country's population. In other words, the rate of infection in BSF is 12.9 times or 1290 percent higher than the national average. Additional border guarding forces are also more or less in the same situation. The problem has become more severe, and authorities have declared many locations of these forces as containment zones.

The reasons for such high rates of infection are manifold. The living conditions at the Border Out Posts (BOPs) along the international borders and Forward Defended Localities (FDLs) along the LOC and LAC are such that the troops have to live in close proximity to each other in barracks. No separate quarantine facilities being available at the BOPs/ FDLs, the troops returning from leave etc. also live in the same barrack where other jawans (soldiers) are residing. Thus, safe distancing norms are difficult to follow, thereby providing a favourable environment for the virus to spread.

With infected troops as well as those quarantined after returning from leave unavailable for duty, border guarding operations are put under severe constraint. Another effect of the pandemic has been on the availability of funds for various activities. A large portion of the budget has been diverted for procurement of COVID-19 kits, etc. leaving little for other activities, thus further hampering logistics on Indian borders.

\section{Borderlands:}

Another issue, especially along the Indo-Pakistan and Indo-Bangladesh border is that the farmers have to cross perimeter fences for farming activities. Troops deployed on fence gates for security screening come into regular physical contact with the farmers, increasing exposure to infection. As per border guidelines with Pakistan (not recognised by India after 1971) and with Bangladesh, no defence-related work can be undertaken within 150 yards of the international border. Since both Pakistan and Bangladesh consider the fence to be a defence-related work, it has been constructed at least 150 yards back from the international line, and most of the land between the fence and boundary is farmland, meaning that the farmers require regular access.

The Border Area Development Programme (BADP) undertaken to develop infrastructure at the borders and to generate employment in border areas has also been severely impacted due to the pandemic. Firstly, the allocation of funds for new projects has been put on low priority. Secondly, even the ongoing projects are delayed due to a severe resource crunch. Besides the shortage of funds, labour shortages have arisen with migratory labour having gone away due to uncertainty of the situation and prolonged lockdown. Local labour is not available in adequate numbers. Farming in the border area has taken a hit due to restrictions on movements during the lockdown period.

We thus find that the COVID-19 pandemic has taken a toll on border security and border management as well as life in the borderlands. It is likely to be a long-term problem as the pandemic has yet to peak and resources necessary to properly carry out full-scale activities on the border are unlikely to be available in a short time.

\section{New internal borders in India:}

After the outbreak of the pandemic, free movement between different states of India too has been restricted. It is the first time in India that states have closed their borders with each other. Road and rail transport having been stopped, and people were compelled to stay at different locations within the country. The poor sections of society were the most severely affected. Millions of people in India migrate to metro cities in search of livelihoods. After the lockdown of the country, the migrant labourers working mainly as daily wagers in unorganised sectors lost their jobs. As per an official estimation, almost 2.6 million labourers remained stuck in different parts of the country. Many also ended up in temporary relief camps that were set up by the government (Chishti 2020). Unable to afford rent and having no money for even food, many migrant labourers started walking to their homes several hundred kilometres away as all modes of transport were stopped during the nationwide lockdown. Many lost their lives in road accidents. Some also died due to hunger and sheer exhaustion. The pandemic thus created an entirely new and previously unimagined set of borders. The two-month nationwide lockdown was lifted, but the harms have not subsided.

\section{Conclusion}

The securitisation of Indian borders varies from country to country depending on the threat perception. In the post-COVID-19 phase, transformation of even open borders is likely, with stricter controls being put in place 
through enhanced surveillance, thermal screening, and enhanced scrutiny of everyone trying to transit. The pandemic has proved that manpower-intensive border guarding practices in India require a rethink. The Indian aviation sector that had registered an impressive rise in previous years is also facing difficulties due to the pandemic. Airports wear a deserted look because of the restrictions imposed. Lastly, intra-state mobility having been restricted throughout India, the economy has been adversely impacted, and the livelihoods of poor people have been severely impacted. The adverse fallout of the pandemic has been in all spheres of life including, centred on borders, and restoration of normalcy is likely to take a long time.

\section{Works Cited}

ANI. 2020. "1,500 Nepali stranded guest workers in Uttarakhand return home". Deccan Chronicle (May 26). Available: https://www.deccanchronicle.com/nation/ current-affairs/260520/1500-nepali-stranded-guestworkers-in-uttarakhand-return-home.html

Bhattarai, Kamal Dev. 2020. Hundreds stuck at sealed India-Nepal border. Govts must manage flow better in Covid-19 times". The Print (April 7). Available: https:// theprint.in/opinion/hundreds-stuck-at-sealed-india-nepal-border-govts-must-manage-flow-better-in-covid-19times/396417/
Chandra, Jagriti. 2019. "Passenger traffic at Indian airports grows $11.6 \%$ to 34.4 crore". The Hindu (April 29). Available: https://www.thehindu.com/business/Industry/passenger-traffic-at-indian-airports-grows-116-to-344-crore/ article26984382.ece

Chishti, Seema. 2020. "Explained: How many migrant workers displaced? A range of estimates". Indian Express (June 8). Available: https://indianexpress.com/article/ explained/coronavirus-how-many-migrant-workers-displaced-a-range-of-estimates-6447840/

Halder, Radhika. 2020. "Lockdowns and national borders: How to manage the Nepal-India border crossing during COVID-19". South Asia@ @SE (May 19). Available: https:// blogs.Ise.ac.uk/southasia/2020/05/19/lockdowns-andnational-borders-how-to-manage-the-nepal-india-border-crossing-during-covid-19/

NewsORB360. 2020. The 5 Most Dangerous Borders in the World" (June 15). Available: https://newsorb360.com/ the-5-most-dangerous-borders-in-the-world/

Tripathi, Dhananjay, and Sanjay Chaturvedi. 2019. "South Asia: Boundaries, Borders and Beyond". Journal of Borderlands Studies 35(2): 173-181. https://doi.org/10.1080/08865655.2 019.1669483

Tripathi, Dhananjay. 2015. "Interrogating Linkages Between Borders, Regions and Border Studies". Journal of Borderland Studies 30(2): 189-201. https://doi.org/10.10 80/08865655.2015.1042010

World Health Organization. 2020. India. Available: https:// www.who.int/countries/ind/ 